Amer. J. Bot. 62(3): 221-231. 1975.

\title{
STOMATAL MOVEMENTS ASSOCIATED WITH POTASSIUM FLUXES ${ }^{1}$
}

\author{
P. Dayanandan and Peter B. Kaufman \\ University of Michigan, Ann Arbor 48104
}

A B S T R A C T

\begin{abstract}
Association of potassium ions with stomatal movements is reported here for 22 different plants. These include Ophioglossum engelmanni, Ginkgo biloba, and Pinus sylvestris. In all 22 plants potassium migrates into the guard cells when stomata open in response to light. In addition, potassium migration into guard cells also occurs with night opening in Crassula argentea and with rhythmic opening in Mimosa pudica. Potassium inside the guard or subsidiary cells, conventionally detected through light microscopic observations of epidermal peels treated with sodium cobaltinitrite reagent, may also be mapped by $\mathrm{x}$-ray microanalysis of such histochemically treated peels, as was the case in this study. In addition to the potassium migration, we also show the movement of chloride as an accompanying anion in Ophioglossum engelmanni, Ginkgo biloba, Plantago rugelii, Begonia sp., and Avena sativa. Eight plants are shown to accumulate potassium inside the stomatal initials or cells of immature stomatal apparatuses; ordinary, immature epidermal cells do not show such an accumulation of potassium. A list in the discussion indicates all the plants in which potassium fluxes associated with stomatal movements have so far been established, including the new examples reported in this paper.
\end{abstract}

HistOCHEMICAL OBSERVATIONS of accumulation of potassium $(\mathrm{K})$ in the guard cells was first observed by Macallum (1905), who introduced the sodium cobaltinitrite reagent as a sensitive indicator of $\mathrm{K}$ in biological materials. Weevers (1911) and Lloyd (1925) also observed this phenomenon but did not propose any role for $\mathbf{K}$ in stomatal function. A connection between $\mathrm{K}$ ion accumulation in guard cells and stomatal opening was first reported by Imamura (1943) and later confirmed by Yamashita (1952). In a series of publications Fujino proposed that stomatal opening and closing are due to the active transport of $\mathbf{K}$ ions into and out of guard cells (Fujino, 1967). Though leaf photosynthesis, transpiration, and stomatal movements have previously been shown to be influenced by $\mathbf{K}$ concentrations in the medium (Iljin, 1957; Snow, 1936), it was Fujino's proposal that first led to a serious investigation of the role of $\mathrm{K}$ ions in stomatal movements (Fischer, 1968, 1972; Willmer and Mansfield, 1970; Humble and Hsiao, 1970; Thomas, 1970). Employing the electron probe microanalyser, Sawhney and Zelitch (1969), Humble and Raschke (1971), and Raschke and Fellows (1971) investigated the quantitative aspects of $\mathrm{K}$ involved in stomatal movements. The possible role of ATP and the effect of inhibitors on $\mathbf{K}$ uptake were investigated by Fujino $(1967,1969)$, Willmer and Mansfield (1970), Thomas (1971), and Pallas (1972).

\footnotetext{
${ }^{1}$ Received for publication 21 January 1974.

The authors wish to thank Prof. Wilbur C. Bigelow and his staff for the scanning electron microscope and $\mathrm{x}$-ray microanalysis facilities and Miss Diane Hoefle for her discussions on the German literature.
}

The influence of $\mathrm{CO}_{2}$ concentration (Pallaghy, 1971), abscisic acid (Mansfield and Jones, 1971), and phytotoxins (Turner, 1973; Arntzen, Haugh, and Bobick, 1973) on $\mathrm{K}$ uptake has also been examined. The possible anions that may be involved in maintaining electroneutrality within the guard cells have been investigated by Humble and Raschke (1971), Raschke and Fellows (1971), Allaway (1973), Pallas and Wright (1973), Willmer et al. (1973), and Raschke and Humble (1973).

Up to the present time, $\mathrm{K}$ involvement in stomatal movements has been reported for 28 species of which twenty were reported in 1973 by Willmer and Pallas. We report here 22 more species, including a pteridophyte and two gymnosperms, for which $\mathbf{K}$ migration is associated with stomatal movements. The present study is also concerned with determination of whether (1) $\mathbf{K}$ fluxes are involved in night opening of stomata and in rhythmic stomatal movements; (2) if chloride ions are the accompanying anions in pteridophytes and gymnosperms; and ( 3 ) if the sodium cobaltinitrite reagent can be employed for quantitative studies of $\mathrm{K}$ in biological materials.

MATERIALS AND METHODS-Source and treatment of plant material-The association of $\mathrm{K}$ and $\mathrm{Cl}$ ions with stomatal movements was observed by histochemical reactions made on leaf epidermal peels. In most cases peels were obtained from intact plants during day or night. The time of the day when stomata were wide open was predetermined by microscopic observations. Plants were grown in a greenhouse or taken from the field 
during the summer of 1973. Where plant material was limited in supply, entire leaves were detached, immersed in distilled water, and exposed to light from a $150 \mathrm{~W}$ reflector flood lamp at a distance of $20 \mathrm{~cm}$. A large Petri dish containing cold running water placed between the lamp and the plant material helped to maintain a constant temperature of $28 \mathrm{C}$ at the level of the leaves. This apparatus was found to be highly effective in opening the stomatal apertures to maximal widths within $1-3 \mathrm{hr}$ in all plants investigated in the present study (Willmer and Mansfield, 1973). Simultaneous preparations were kept in the dark at $28 \mathrm{C}$ to induce closure of the stomata.

In a search for crassulacean or other succulents which are known to exhibit night opening of stomata, the jade plant (Crassula argentea) was found to show a striking dark stomatal opening. Opening was initiated immediately after the end of a 12-hr photoperiod. The stomata continued to open wider in the dark and reached maximum aperture widths about $5 \mathrm{hr}$ after the onset of the dark period.

Rhythmic stomatal movements-In the analysis of rhythmic movements associated with potassium fluxes in the sensitive plant, Mimosa pudica, we used 10-week-old plants that were raised from seeds in a greenhouse. They were transferred to an air-conditioned room set at $29 \mathrm{C}$ and given a 12-hr daily photoperiod regime for two weeks. Irradiation from a light source of three cool-white fluorescent lamps and four $100 \mathrm{~W}$ incandescent lamps provided $1.5 \times 10^{4} \mathrm{ergs} / \mathrm{cm}^{2}$ per sec in the spectral range of $300-800 \mathrm{~nm}$. The temperature remained a constant $28 \mathrm{C} \pm 1$ throughout the experiment. After 2 weeks, at the end of a 12-hr light period, three of the six plants were transferred to a dark chamber set at $28 \mathrm{C}$. The $\mathrm{CO}_{2}$ concentration in the experimental chambers was maintained at $300 \pm 10 \mathrm{ppm}$. Relative humidity varied between $54-56 \%$. For the next three days, starting one hour before the onset of a given photoperiod, hourly examinations were made for 48-72 hr on the width of the stomatal apertures and on the position of the leaflets of plants kept under both light and dark regimes. A green safelight was used to examine the plants kept under continuous darkness. Stomatal aperture width was measured with an ocular micrometer; fifty measurements were made on each abaxial surface of each leaflet examined.

Histochemical reaction for potassium-A modification of Macallum's sodium cobaltinitrite reaction was used to localize $\mathrm{K}$ in the stomatal apparatuses (Macallum, 1905). For K localization in most stomata, fresh $5-10 \%$ solutions were prepared by dissolving commercial sodium cobaltinitrite reagent (J. T. Baker Chemical Co.) in distilled water and by acidifying this solution with glacial acetic acid (one drop per $10 \mathrm{ml}$ ). For smaller stomata, as occur in Mimosa pudica, higher concentrations of the reagent $(20-40 \%)$ were required to precipitate $\mathrm{K}$ effectively. Higher concentrations were also required for the epidermal peels of Psilotum nudum and Pinus sylvestris. These peels had several subepidermal cells which had to be scraped away after treatment. Epidermal peels were floated on deionized water for 10 sec and transferred to the sodium cobaltinitrite reagent for 15-30 min. Both the steps and the rinses which followed were carried out with water and reagent that were precooled to $0 \mathrm{C}$ on an ice bath. The treated peels were placed in deionized water for one $\mathrm{min}$, the treatment repeated with fresh deionized water for an additional minute, and then mounted in $10 \%$ ammonium sulfide in $5 \%$ glycerine. This treatment results in deposits of black cobalt sulfide. Wax blooms on the epidermal surfaces of leaves, as exemplified by $M i-$ mosa pudica, some crassulacean members, and Avena sativa, interfere with the microscopic observation of these stained peels. This was obviated by rinsing the peels in $50 \%$ tert. butyl alcohol at $0 \mathrm{C}$ for $2-3 \mathrm{~min}$ before mounting the peels in $\left(\mathrm{NH}_{4}\right)_{2} \mathrm{~S}$. Stained peels can be made permanent by dehydrating the tissue with ethanol and mounting in "Permount."

Histochemical reaction for chloride-Procedures similar to those of Raschke and Fellows (1971) were employed to localize $\mathrm{Cl}$ ions with silver nitrate. (Saturated $\mathrm{NaNO}_{2}$ was used to determine the presence of reducing substances that may precipitate silver, and thus may give false results (Metzner, 1952)). The precipitating procedures were carried out under both light and dark conditions (see Observations).

$X$-ray microanalysis-A scanning electron microscope (JSM-U3) coupled to KEVEX x-ray detector and amplifier systems and to a multichannel analyser (Northern Scientific, Model 710) was used to detect and map the distribution of $\mathrm{K}$ and $\mathrm{Cl}$ through their $\mathrm{K} \alpha$ X-ray emissions. Both freeze-dried epidermal peels and those treated with the above-mentioned reagents to precipitate $\mathrm{K}$ and $\mathrm{Cl}$ were employed. The epidermal peels for freeze-drying and for precipitation treatments were obtained from the same leaf or leaf segment. Epidermal peels treated with precipitating reagents were rinsed thoroughly in deionized water, folded in clean aluminum foil, and dried in a desiccator. The peels were mounted on carbon stubs and coated with carbon before examination.

The scanning electron microscope was operated at an accelerating voltage of $25 \mathrm{KeV}$. To compare the $\mathrm{x}$-ray counts in freeze-dried peels with those in which the ions had been precipitated, the instru- 


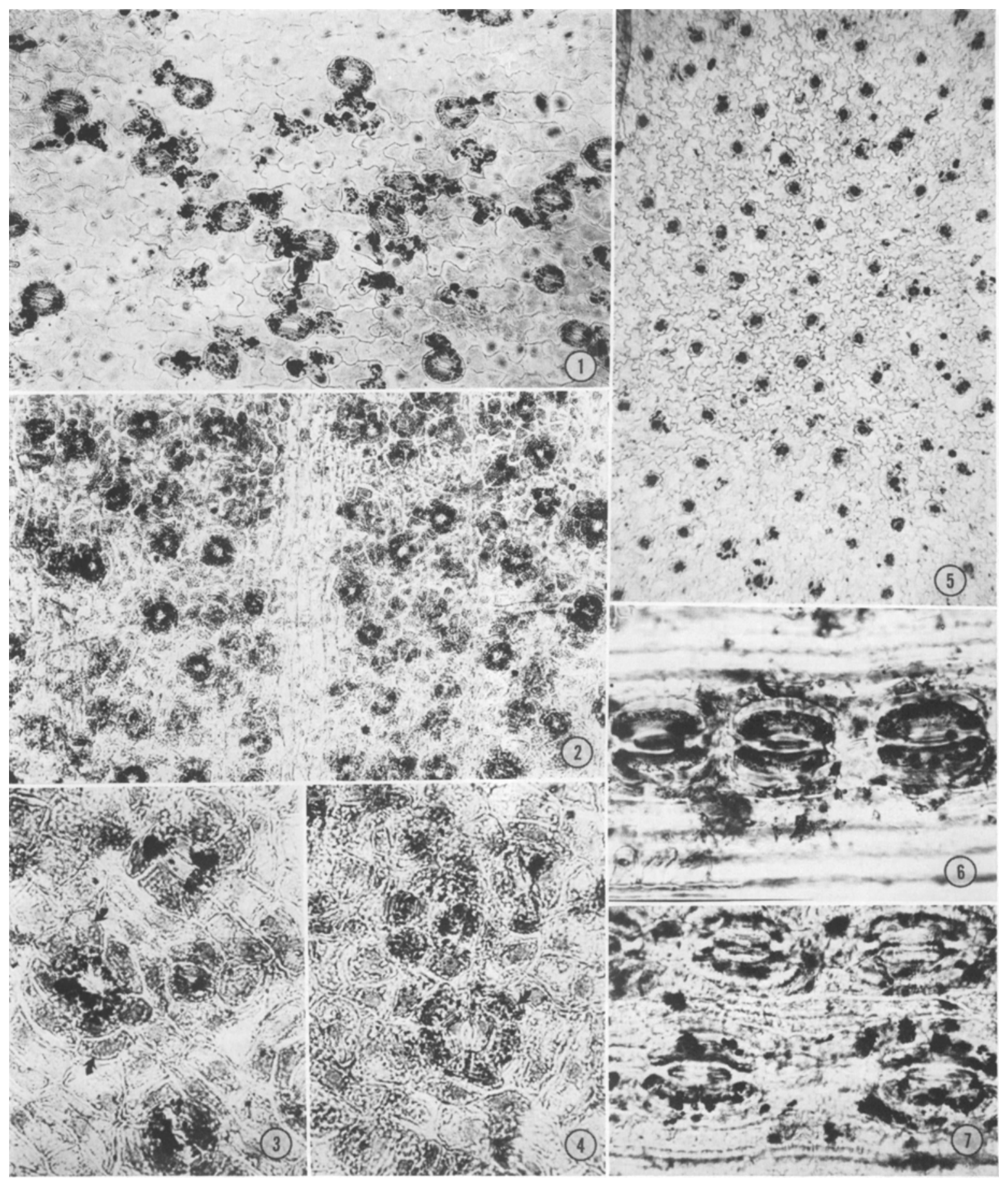

Fig. 1-7. Results of histochemical treatments to localize K. 1. K localization in the epidermis of Ophioglossum engelmanni. Even though the stomata were open, some $\mathbf{K}$ can be observed in subsidiary and other epidermal cells. $\times 95.2$. Abaxial epidermis of leaf obtained from an intact tree of Ginkgo biloba at 2 P.M. Stomata were wide open. $\times 100$. 3. View of three stomata that opened in response to artificial illumination. A developing stomatal complex in the center of this figure shows K inside the young guard cells. Ginkgo biloba. $\times 260.4$. Preparation similar to that in Fig. 3, but kept in total darkness to close the stomata. Arrows point to the subsidiary cells. $\times 260.5$. Potassium localization inside the guard cells of light-treated Kalanchoe fedtschenkoi. $\times 60.6$, 7. Potassium distribution in opened and closed stomata of Pinus sylvestris. Pinus has 4-6 subsidiary cells that overlap the sunken guard cells. Both $\times 500$. 


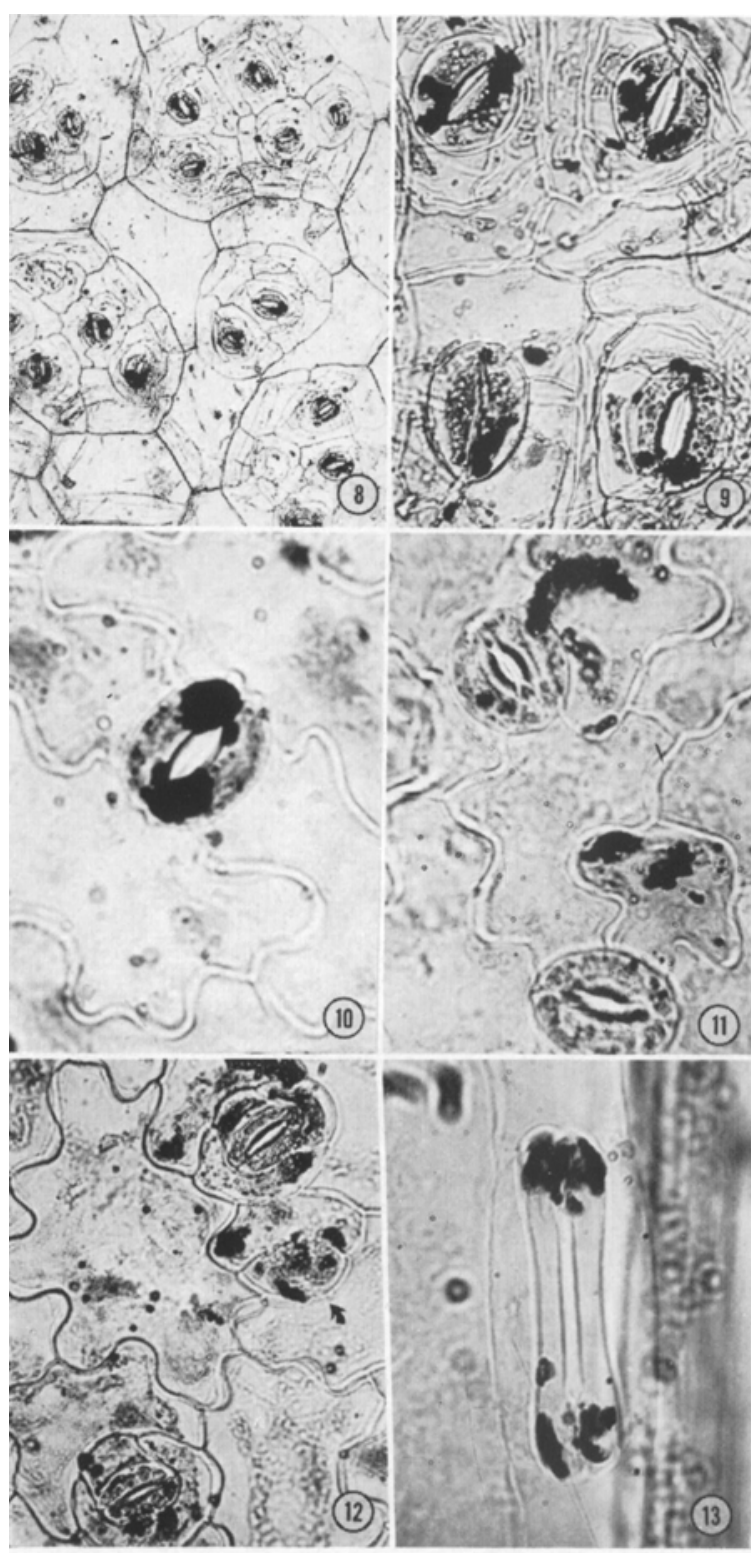

Fig. 8-13. Results of histochemical treatment to localize K. 8, 9. Light-induced stomatal opening in leaf segments of Begonia sp. 8. $\times 150 ; 9 . \times 590$. 10. Opened stoma of Plantago rugelii. This preparation was made at 2 P.M. from a plant growing in the field. $\times 650.11$. Preparation made from the same plant at 10 P.M. $\times 620$. 12. Arrow points to a developing stomatal complex in the epidermis of dark-treated Kalanchoe fedtschenkoi. All the young cells contain K. Potassium is also found inside the mature subsidiary cells. $\times 400$. 13. Potassium in the bulbous ends of guard cells of an opened stoma of Avena sativa. Epidermis obtained from an intact plant. $\times 800$

ment operation, the magnification factors, and the type and size of the area of the peel examined were all maintained at essentially identical conditions.
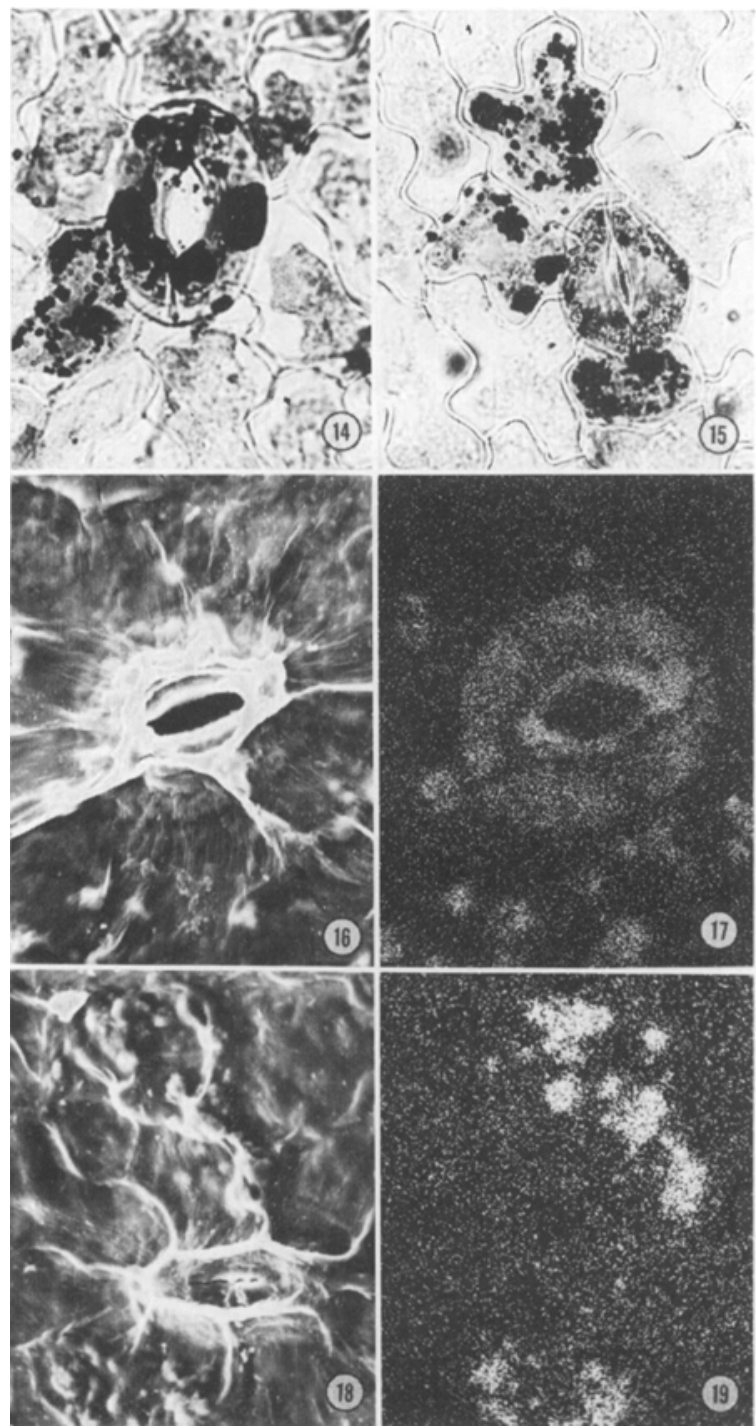

Fig. 14-19. Results of histochemical reaction and $\mathrm{x}-$ ray microanalysis for $\mathbf{K}$ in light or dark-treated leaf segments of Ophioglossum engelmanni. 14. Potassium inside the guard cells of an open stoma. $\times 330$. 15. $\mathrm{K}$ inside the subsidiary cells of a dark-treated epidermis. $\times 280$. 16, 18. The epidermal peels were treated with sodium cobaltinitrite reagent but not with ammonium sulfide. 16. Scanning electron microscope view of a stoma of light-treated material. $\times 400$. 17. X-ray image of $\mathrm{K}$ of the same material as in Fig. $16 . \times 400.18,19$. Scanning electron microscope view and $x$-ray analysis for $K$ of a closed stomatal apparatus. Both $\times 400$.

OBSERVATIONS-Potassium localization-Potassium was localized within the guard cells of stomata that had opened in light (Fig. 3, 5, 6, 9, 14, 20,26 ). In Avena sativa $\mathbf{K}$ is localized primarily in the bulbous ends of the guard cells (Fig. 13). About $10 \%$ of the guard cells of $A$. sativa showed localization, even in the tubular regions (Fig. 20). In Ophioglossum engelmanni and Pinus syl- 
vestris, some $\mathrm{K}$ was retained within the subsidiary cells, even when the stomata were fully open (Fig. 1, 6 and 7).

For closed stomata $\mathrm{K}$ was localized outside the guard cells (Fig. 4, 7, 11, 15, 21, 28). In Ophioglossum engelmanni, which has no morphologically well-characterized subsidary cells, 1-3 epidermal cells adjoining the guard cells accumulated $\mathrm{K}$ during stomatal closure (Fig. 1, 15). Neutral red uptake and counts of chloroplasts numbers indicated that about $95 \%$ of the epidermal cells were intact. A rough approximation of guardcell $p \mathbf{H}$ with $p \mathbf{H}$ indicator solutions showed that the $p \mathrm{H}$ in Ophioglossum engelmanni changed from 5.6 to 6.4 when fully closed stomata opened and reached a full aperture width of $14 \mu \mathrm{m}$. The corresponding $p \mathrm{H}$ values for the subsidiary cells were 6.9 and 5.8. In Ginkgo biloba and Pinus sylvestris, each of which possesses 4-6 subsidiary cells and sunken stomata, $K$ was found in all the subsidiary cells during stomatal closure (Fig. 4, 7). In Begonia sp. no potassium could be localized within the subsidiary cells. Apparently, potassium migrated to other epidermal cells or to mesophyll cells. Begonia sp. was also unusual in that its stomata could open widely, even in the dark, if the leaves were kept immersed in water. Potassium entered the guard cells during this stomatal opening. The stomata remained permanently open for 4 or more days until the leaf began to senesce and decay.

Small epidermal trichomes in Avena sativa and Oryza sativa and basal regions of epidermal hairs in Saxifraga sarmentosa, Commelina coeltis, and Vinca rosea also contained $K$, whether the stomata were open or not. Certain epidermal cells, not in association with guard cells, also contained potassium in Ophioglossum engelmanni (Fig. 1). Such cells have also been described in Bryophyllum tubiflorum (Willmer and Pallas, 1973) and in Zea mays (Raschke and Fellows, 1971). In Ginkgo biloba, Kalanchoe fedtschenkoi, and Begonia sp., the epidermal preparations also contained stomatal initials and cells of stomatal complexes in varying stages of development. All these young cells also contained $\mathrm{K}$. Potassium distribution remained undisturbed in these cells when mature stomata closed or opened (Fig. 2, 3, 5, 12). Epidermal peels were also obtained from young leaves of Ophioglossum engelmanni, Avena sativa, Vicia $f a b a$, and Crassula argentea. These leaves had stomata in varying stages of development. Most of the immature cells of the stomatal apparatuses also contained $\mathrm{K}$. Immature ordinary epidermal cells did not accumulate $\mathrm{K}$ during their developmental stages.

Potassium in night opening of stomata-In Crassula argentea, which showed night opening, $\mathbf{K}$ accumulated inside the guard cells during stomatal opening (Fig. 30, 31). Though the stomata

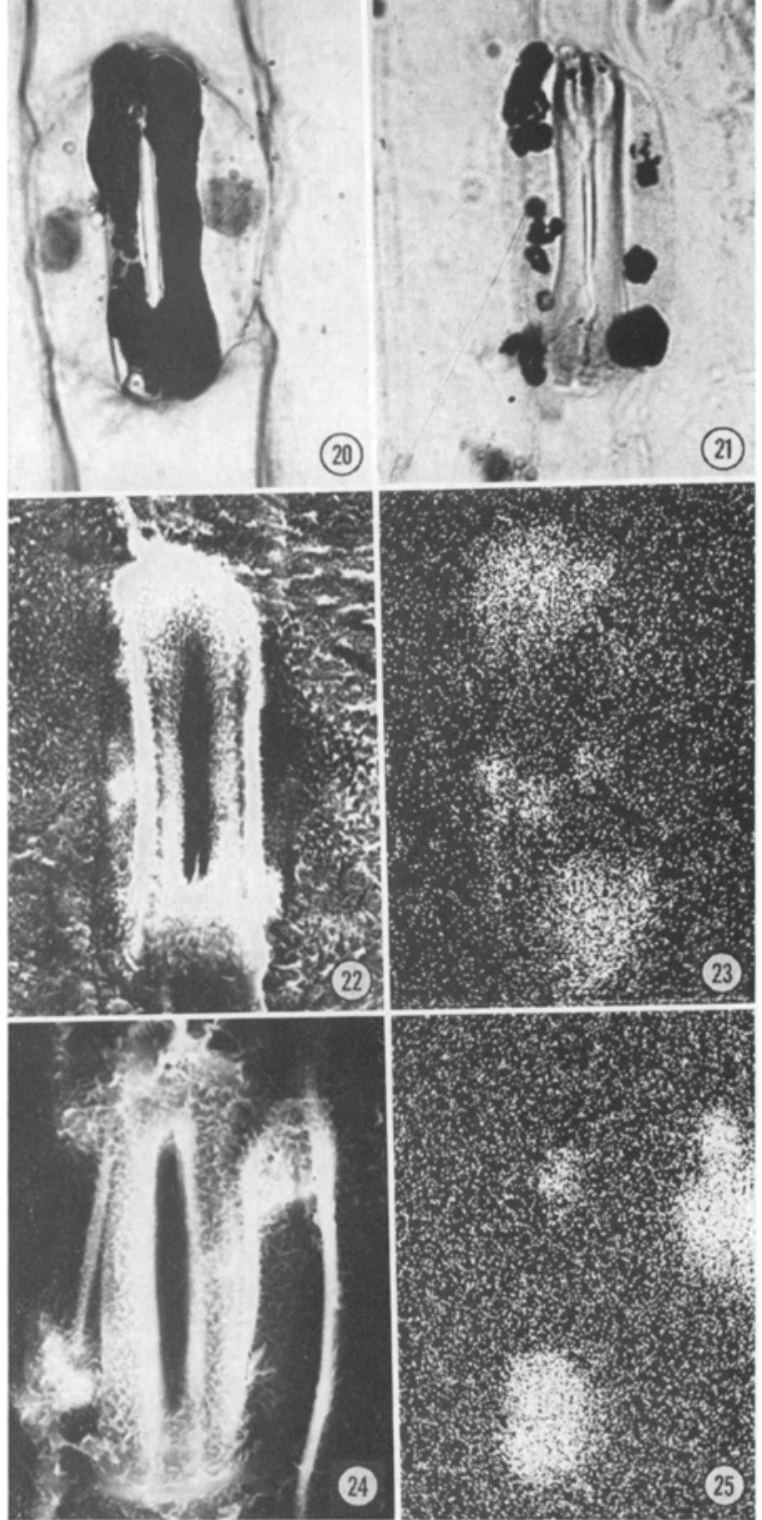

Fig. 20-25. Results of histochemical reaction and $x-$ ray microanalysis for $\mathrm{K}$ in Avena sativa. Intact plants were kept in bright light or total darkness to open or close the stomata. 20, 21. Potassium distribution in opened and closed stomata. Both $\times 800$. 22, 23. Scanning electron microscope view and $\mathrm{x}$-ray image of $\mathrm{K}$ of a single opened stomatal apparatus. Both $\times 1000$. 24, 25. Scanning electron microscope view and $x$-ray image of $\mathrm{K}$ of one closed stomatal apparatus. The drying procedure has distorted the cells and caused the apparent widening of stomatal aperture. Both $\times 1000$.

did not close completely during the day, no significant quantities of $K$ could be detected inside the guard cells. Potassium did accumulate inside the guard cells, however, when stomata were forced to open wider during daytime by immersing the leaves in water and exposing to light. 


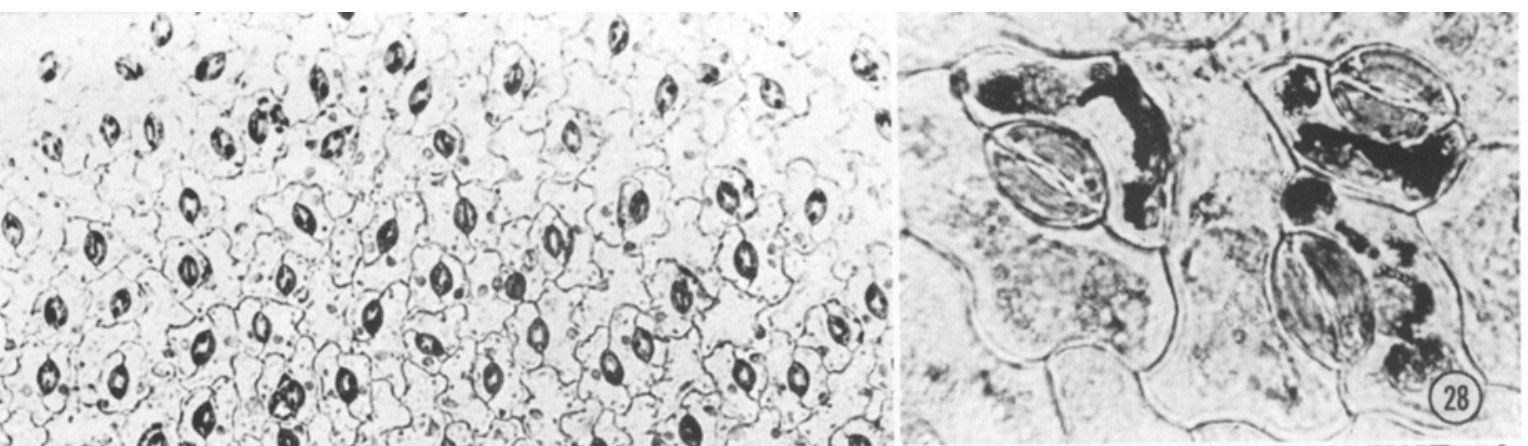

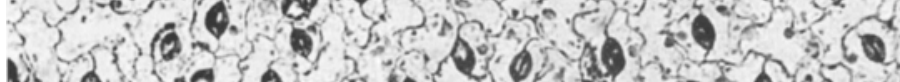

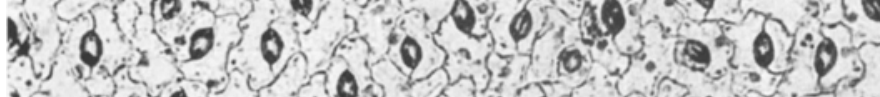

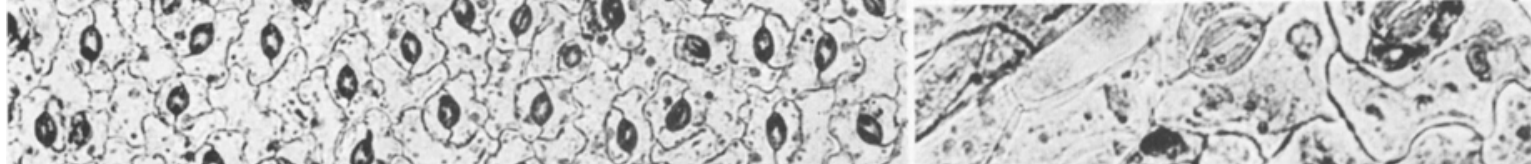

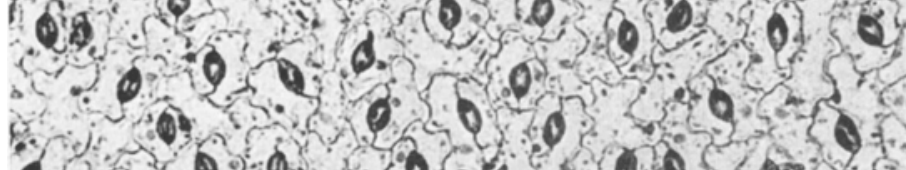

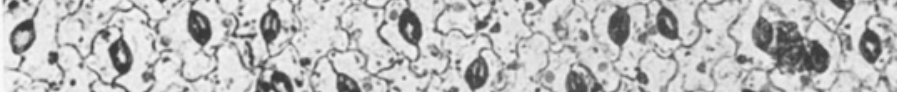

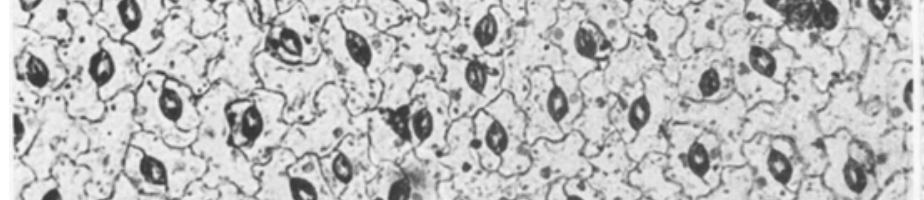

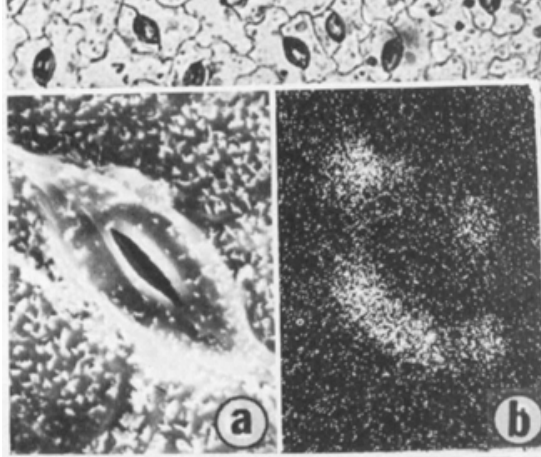

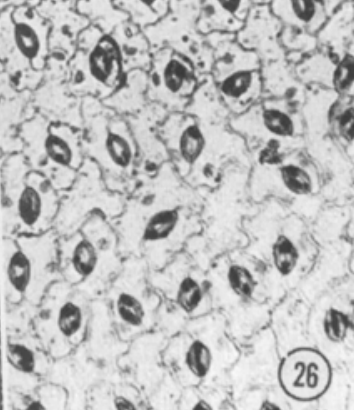
7. $1 .+2$ (4) (2)

Fig. 26-31. Results of histochemical reaction for K. 26. Abaxial epidermis of a leaflet from an intact plant of Mimosa pudica exposed to $8 \mathrm{hr}$ of light. $\times 150$. 26a, 26b. Scanning electron microscope view and $x$-ray image of $\mathrm{K}$ of a guard cell obtained from the above mentioned plant. This preparation was not treated with ammonium sulfide. Both $\times 1125$. 27. K inside the guard cells of Mimosa pudica. The stomata had opened because of a rhythm. This plant was in total darkness, and the preparation was made simultaneously with that in Fig. 26. $\times$ 400. 28. Mimosa pudica plants that had grown in alternating periods of light and dark. Potassium was local- 
Potassium in rhythmic stomatal movementsIn Mimosa pudica leaflet movements in plants kept under continuous darkness showed a lesspronounced but essentially similar pattern as shown by those receiving alternate periods of 12$\mathrm{hr}$ light and 12-hr darkness. This pattern was repeated during the three days of continuous darkness and confirms the existence of an endogenous rhythm for leaflet movements.

Direct microscopic observation of the stomata on the lower surface of the leaflets revealed that the stomata were already slightly open before the onset of the light period. Stomata of plants growing under alternating dark and light periods responded to light and reached an aperture width of $3.5 \mu \mathrm{m}$ within $1-2 \mathrm{hr}$ after the onset of light. Stomatal closure was evident after about $10 \mathrm{hr}$ of light, and almost complete closure occurred just before the end of the photoperiod. The behavior of the stomata in plants kept in continuous darkness followed similar rhythmic stomatal movements. However, aperture size changes were less (about 2 times less than those recorded for plants kept in alternating light and dark). This rhythmic opening never exceeded a width of $3.5 \mu \mathrm{m}$, whereas the maximum aperture width for plants growing under alternating periods of light and darkness was $5 \mu \mathrm{m}$, which occurred about $7 \mathrm{hr}$ after the onset of light. Complete closure occurred 1-2 hr earlier in plants under continuous darkness. The rhythm persisted, though dampened, even on the third day.

Potassium was found to be localized in the guard cells both for stomata that opened in light and for those in continuous darkness. Figure 26 shows $\mathrm{K}$ localization in a peel taken $8 \mathrm{hr}$ after the onset of light on the first day of the experiment. A preparation made simultaneously from plants in continuous darkness showed $\mathbf{K}$ inside the guard cells; however, some $\mathbf{K}$ still remained in the subsidiary and epidermal cells (Fig. 27). No K was found in the guard cells when stomata closed in both the treatments. Figure 29 illustrates a preparation made from plants kept in continuous darkness. It shows the localization of $\mathbf{K}$ in the subsidiary cells after the beginning of the first day of the experiment. Although $\mathbf{K}$ was never detected in stomata that were closed, localization in the subsidiary cells was not always observed. This was probably due to a rapid translocation of $\mathrm{K}$ to other parts of the leaf.

At the end of the third day of the experiment, the plants growing in alternate light and dark periods were kept in continuous light. Stomatal behavior under these conditions was very similar to the rhythmic movements described above for plants kept in total darkness. However, an additional opening of stomata to a width of $2 \mu \mathrm{m}$ was observed after $16-17 \mathrm{hr}$ of continuous light on the first day of such treatment. Smaller but detectable quantities of $\mathbf{K}$ were localized in the guard cells during this opening. Under continuous light the leaflets remained open 3-4 hr after their usual time of closure.

Mimosa pudica possesses about 35 modified stomata at the base of every leaflet, localized on the upper surface of the pulvinule. Their guard cells are flanked by two subsidiary cells each of which is filled with anthocyanin. Though the aperture between the guard cells appeared to be open during light treatments, $\mathrm{K}$ localization could not be assessed because of the difficulty in obtaining epidermal peels from this region. The significance of these specialized stomatal apparatuses in the photoreceptive pulvinular region is not known.

$X$-ray microanalysis - X-ray microanalysis of freeze-dried epidermal peels essentially confirms the histochemical observations; namely, that $\mathrm{K}$ accumulates inside the guard cells during stomatal opening and inside the subsidiary cells during stomatal closure. Epidermal peels treated with the sodium cobaltinitrite reagent would contain precipitates of $\mathrm{Na} \mathrm{K}_{2} \mathrm{Co}\left(\mathrm{NO}_{2}\right)_{6}$ in regions where $\mathrm{K}$ was present. The $\mathrm{x}$-rays emitted from these elements could therefore be used to map the location of $\mathrm{K}$. We found that only the $\mathrm{X}$-rays emitted from $\mathrm{K}$ were of any significance (Fig. 16-19, 22$25,26 a, b)$. Since the reagent cannot be entirely washed away from the epidermal peels, the X-ray images of $\mathrm{Na}$ and Co show a more or less uniform distribution throughout the epidermal surface.

The average count of $\mathrm{x}$-ray emission of $\mathrm{K}$ from guard cells from samples treated with sodium cobaltinitrite reagent was very close to that of guard cells of freeze-dried samples (252:240 counts per three minutes for Ophioglossum engelmanni and 180:172 for Avena sativa). This may indicate the efficiency of sodium cobaltinitrite reagent as a $\mathrm{K}$ localizer and its possible use in quantitative studies (Crout and Jennings, 1957). However, the values from freeze-dried and chem-

ized only inside the subsidiary cells of stomata as they closed in the dark period. $\times 625$. 29. Preparation made from a plant kept in total darkness. Stomatal closure occurred rhythmically. This plant has been in total darkness for $12 \mathrm{hr}$ on the first day of experiment. $\times 375$. 30. Epidermis from Crassula argentea, showing $\mathrm{K}$ localization inside the guard cells of night-opened stomata. The plant was grown in alternating $12 \mathrm{hr}$ light and $12 \mathrm{hr}$ dark periods. This preparation was made at 1 A.M. when the stomata were wide open. $\times 100$. 31. A preparation made from a second $C$. argentea plant at 12 midnight. $\times 300$. 


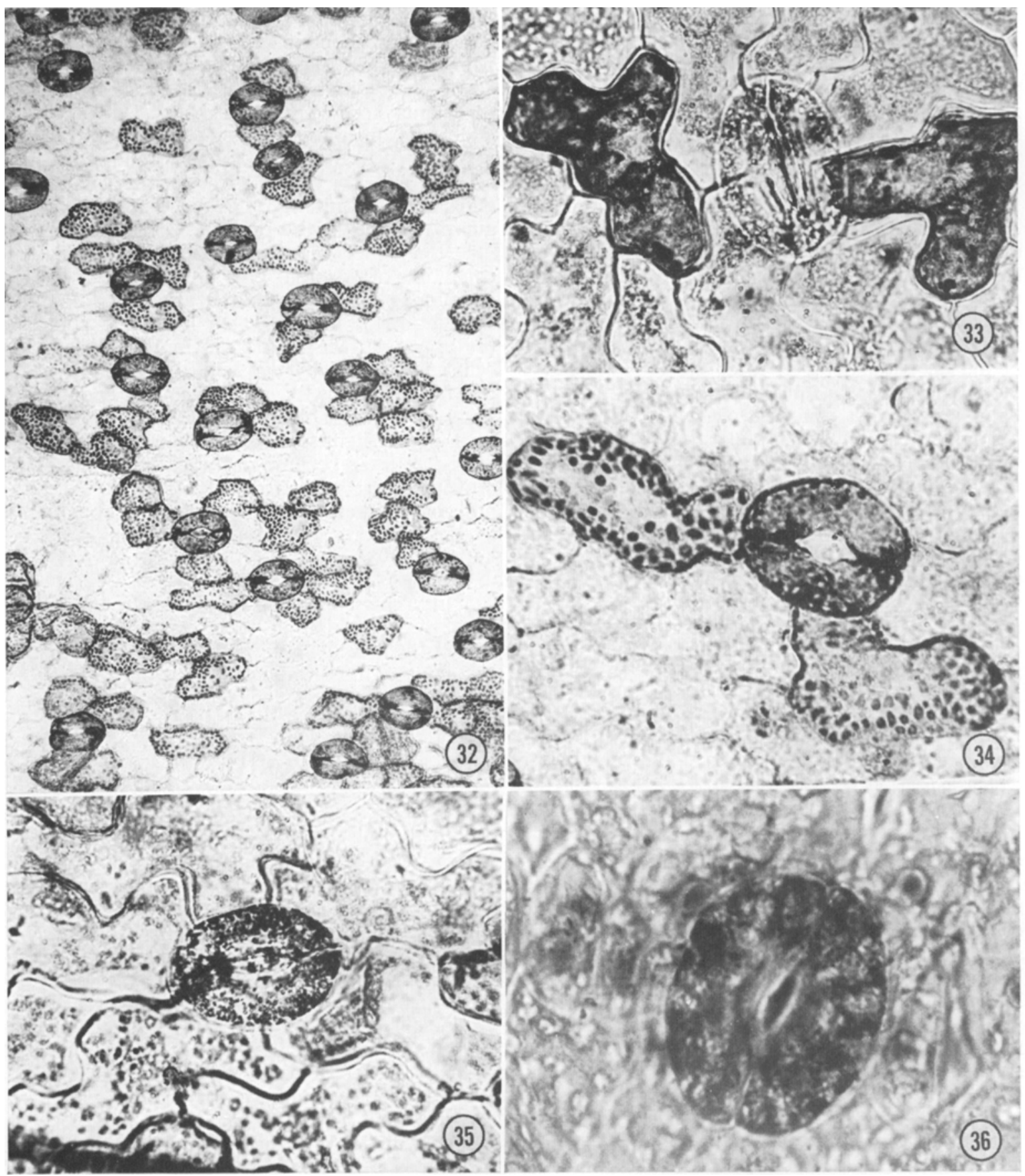

Fig. 32-36. Results of histochemical reaction to localize Cl.-Fig. 32-35. Ophioglossum engelmanni. $32,34$. These epidermal peels were obtained from leaf segments kept in total darkness. The histochemical procedures were done in front of a bright light source. Reduced silver grains are seen on chloroplasts. The apparent aperture opening resulted from dehydration during permanent slide making procedures. 32 . $\times 115 ; 34$. $\times 280$. 33. Epidermis from the above source treated under dark conditions. Silver grains appear evenly distributed in the cytoplasm. $\times 280$. 35. Chloride inside the guard cells in an opened stoma treated under dark conditions. $\times 280$. 36. Chloride inside the opened guard cells of Ginkgo biloba. This epidermis was obtained from an intact plant at 1 P.M. $\times 800$. 
TABLE 1. List of plants in which $K$ fluxes are known to be associated with stomatal movements

\begin{tabular}{|c|c|c|c|}
\hline & Present study & & Previous reports \\
\hline & & 12 & \\
\hline Pteridophytes & Ophioglossum engelmanni & ++ & Polypodium aureum \\
\hline Gymnosperms & $\begin{array}{l}\text { Ginkgo biloba } \\
\text { Pinus sylvestris }\end{array}$ & $\begin{array}{r}+ \\
+\end{array}$ & - \\
\hline Dicotyledons & $\begin{array}{l}\text { Begonia } \times \text { cheimantha } \\
\text { Crassula argenta } \\
\text { Desmodium gyrans } \\
\text { Galium sp. } \\
\text { Impatiens sultanii } \\
\text { Kalanchoe fedtschenkoi } \\
\text { K. marmorata } \\
\text { Mimosa pudica } \\
\text { Plantago rugelii } \\
\text { Pedilanthus sp. } \\
\text { Plectranthus australis } \\
\text { Saxifraga sarmentosa } \\
\text { Synadenium granti rubrum } \\
\text { Taraxacum officinale } \\
\text { Vicia faba } \\
\text { Vinca rosea } \\
\quad- \\
\quad-\end{array}$ & $\begin{array}{r}+ \\
+ \\
+ \\
+ \\
+ \\
+ \\
+ \\
+ \\
+ \\
+ \\
+ \\
+ \\
+ \\
+ \\
+ \\
+ \\
+ \\
+ \\
+ \\
+ \\
+\end{array}$ & $\begin{array}{l}\text { Arachis hypogea } \\
\text { Carya sp. } \\
\text { Forsythia sp. } \\
\text { Kalanchoe blossfeldiana } \\
\text { K. pinnata } \\
\text { Liquidambar styraciflua } \\
\text { Lonicera japonica } \\
\text { Magnolia grandiflora } \\
\text { Nicotiana tabacum } \\
\text { Pelargonium zonale } \\
\text { Phaseolus vulgaris } \\
\text { Pisum sativum } \\
\text { Quercus nigra } \\
\text { Rheum rhaponticum } \\
\text { Rhododendron sp. } \\
\text { Rubus sp. } \\
\text { Senecio odoris } \\
\text { Vicia faba }\end{array}$ \\
\hline Monocotyledons & $\begin{array}{l}\text { Avena sativa } \\
\text { Asparagus falcatus } \\
\text { Commelina coeltis } \\
\text { Oryza sativa } \\
\text { Rhoeo discolor } \\
\text { Zea mays } \\
\text { Zebrina pendula }\end{array}$ & 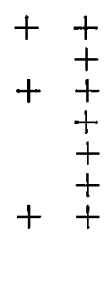 & $\begin{array}{l}\text { Allium cepa } \\
\text { Avena sativa } \\
\text { Commelina communis } \\
\text { Hordeum vulgare } \\
\text { Musa sp. } \\
\text { Tradescantia reflexa } \\
\text { Tulipa sp. } \\
\text { Zea mays } \\
\text { Zebrina pendula }\end{array}$ \\
\hline
\end{tabular}

${ }^{1}$ Epidermal peels obtained from intact plants.

${ }^{2}$ Epidermal peels obtained from detached leaves or leaf segments.

ically treated materials cannot be legitimately compared (Lauchli, 1972).

In Mimosa pudica the subsidiary cells contain a tannin-like material that showed precipitation reaction properties similar to $K$. Thus, in some preparations, in stomata that were open in light, a precipitate was found both in the guard and subsidiary cells. But when such a peel was used for $\mathbf{X}$-ray microanalysis, $\mathbf{K}$ could be mapped only in the guard cells (Fig. 26b).

Chloride ions-In Ophioglossum engelmanni, Ginkgo biloba, Plantago rugelii, Avena sativa, and Zea mays, $\mathrm{Cl}$ was found to be localized inside the guard cells of opened stomata and inside the subsidiary cells of closed stomata (Fig. 32-36). In Ophioglossum engelmanni, which was investigated in greater detail, the cellular location of $\mathrm{Cl}$ was different under two different treatments. When the histochemical procedure (floating epidermal peels on $5 \% \mathrm{AgNO}_{3}$ solution for $5 \mathrm{~min}$ ) was carried out in light, silver grains were localized on the chloroplasts of subsidiary cells (Fig. 32, 34) when the peels had closed stomata. If the same reaction was carried out in total darkness or in green safelight, the silver grains were found evenly distributed in the cytoplasm (Fig. 33). When the epidermal peel had open stomata, no such difference was recognized in the distribution of silver grains inside the guard cells (Fig. 35). When such a peel with opened stomata was treated in light, some darkening of the chloroplasts of the subsidiary and other epidermal cells was seen. Xray analysis of freeze-dried samples of Ophioglossum engelmanni showed that the accumulation of $\mathrm{K}$ and $\mathrm{Cl}$ occurs inside the same subsidiary cells.

Discussion-Table 1 lists the species of plants in which $\mathrm{K}$ involvement in stomatal movements is known to occur. This list includes previous reports on 28 different plants and our own studies on 22 different plants. In addition, we have also confirmed the existence of $\mathbf{K}$ fluxes in plants that have been investigated before. Among these 50 plants, Vicia faba has received most attention. For all plants listed in Table 1, with the exception 
of Asparagus falcatus, the epidermal peels were derived from leaves. However, Willmer and Pallas (1973) have shown involvement of $\mathrm{K}$ fluxes in the movements of stomata that were obtained from awns (Hordeum vulgare), sepals (Pelargonium zonale), and cotyledons (Glycine max). The previous reports include only one fern, Polypodium aureum, and no gymnosperms. We have found definite $\mathrm{K}$ fluxes in Ophioglossum engelmanni, Ginkgo biloba, and Pinus sylvestris. We have also found $\mathbf{K}$ localization within the guard cells of Psilotum nudum during stomatal opening. A definite flux was not established in this plant or in Selaginella, Equisetum hyemale, $E$. variegatum, and Nephrolepis bostoniana. The complexity of the stomatal apparatus in Equisetum (Dayanandan and Kaufman, 1973) and the difficulty in obtaining monolayer epidermal peels from Psilotum, make these plants difficult to investigate by the methods described herein. However, the occurrence of $\mathrm{K}$ fluxes in Ophioglossum, Polypodium, Pinus, Ginkgo, as well as several dicots and monocots, suggests that this feature may be common to plants of all evolutionary levels (Willmer and Pallas, 1973). Our finding that $\mathrm{K}$ is involved in the stomatal opening of Kalanchoe marmorata and in the night opening of Crassula argentea calls for a reinvestigation of the few studies which have suggested $\mathrm{Na}$ as a possible cation (Thomas, 1970).

Stomata are known to respond to various internal and external factors. Previous reports have shown the involvement of $\mathrm{K}$ in stomatal movements influenced by light (Raschke and Fellows, 1971; Willmer and Pallas, 1973), $\mathrm{CO}_{2}$ concentrations (Pallaghy, 1971; Thomas, 1971), and abscisic acid (Mansfield and Jones, 1971). The present report shows that $\mathrm{K}$ fluxes are associated with night opening and rhythmic movements. It appears, therefore, that, irrespective of the mechanisms through which the various factors may influence stomatal opening, accumulation of $\mathrm{K}$ seems to be a common feature. This does not necessarily imply that $\mathrm{K}$ uptake is the primary cause of a decrease in water potential (Mansfield and Jones, 1971; Raschke and Humble, 1973). It is of interest, however, to note that other rapid movements of leaflets and leaves in some plants (Mimosa pudica, Samanae saman, Albizzia julibrissin) are also associated with $\mathrm{K}$ fluxes (Evans and Allaway, 1972).

In all eight species studied, stomatal initials or immature cells of stomatal complexes showed accumulation of $\mathbf{K}$. Such an accumulation of $\mathbf{K}$ into stomatal cells that are incapable of normal functioning may well be a common feature in many other species. This accumulation may ensure the ready availability of $\mathrm{K}$ when the stomata become functional. Potassium may also be a requirement for the normal development of stomatal appa- ratuses. Whether or not elements other than $\mathbf{K}$ also accumulate inside the immature stomatal cells needs to be determined.

Humble and Raschke (1971) and Raschke and Fellows (1971) presented quantitative evidence that in Vicia faba and Zea mays $\mathrm{Cl}$ neutralized .05 and .40 of the positive charge of $\mathrm{K}$ within the guard cells during stomatal opening. We have found fluxes of $\mathrm{Cl}$ associated with stomatal movements in Ophioglossum, Ginkgo, Avena, and Plantago. Allaway (1973) reported that in Vicia faba about one-half of the $\mathbf{K}$ taken up during stomatal opening could be balanced by malate. Pallas and Wright (1973) found considerable increase in glycerate, malate, and citrate in the epidermis of Vicia faba during stomatal opening. Willmer et al. (1973) detected high levels of phosphoenolpyruvate carboxylase in the guard cells of two $\mathrm{C}_{3}$ plants, Commelina communis and Tulipa gesneriana. This enzyme can produce oxaloacetate from which other organic acids can be produced that can act as anions. Raschke and Humble (1973) have shown that in Vicia faba, hydrogen ions are exchanged for potassium ions during stomatal opening. The excretion of hydrogen ions by the guard cells during stomatal opening is further evidence that organic anions may help to maintain electroneutrality inside the guard cells. It appears, therefore, that in different plants inorganic $\mathrm{Cl}$ and a number of organic anions may, in various proportions, neutralize the positive charge of $\mathrm{K}$ taken up by the guard cells.

The observations on the reduction of silver in the epidermal peels in Ophioglossum engelmanni are not easily explained. Electron microscopic studies indicate that the reduced silver particles are associated with the stroma lamellae of chloroplasts (Brown, Mollenhauer, and Johnson, 1962). Previous studies of this seemingly complex phenomenon of silver nitrate reduction by chloroplasts have been summarized by Rabinowitch (1945).

Sodium cobaltinitrite is known to be very sensitive for the localization of $\mathrm{K}$ (Macallum, 1905). Our X-ray analysis data on freeze-dried peels, compared with data from peels in which $\mathbf{K}$ has been precipitated by this reagent, supports the conclusion that sodium cobaltinitrite could be used for quantitative studies on biological materials (Crout and Jennings, 1957). In recent years certain new reagents have come into use as sensitive agents for $\mathbf{K}$ estimation in analytical chemical procedures. These include sodium tetraphenyl boron, sodium dodecyl sulphate, and bismuth nitrate + thiosulphate. These reagents should be investigated for their usefulness in the localization of $\mathbf{K}$ in biological materials. Our preliminary investigations show that a major disadvantage would be their relatively poor penetration properties with some plant tissues. When epidermal peels of Avena sativa with opened stomata are 
treated with a $1 \%$ solution of sodium tetraphenyl boron, slight but immediate precipitation occurs near the periphery of the bulbous ends of guard cells. Further crystal growth occurs only on the outer surfaces of the bulbous ends of guard cells.

\section{LITERATURE CITED}

Allaway, W. J. 1973. Accumulation of malate in guard cells of Vicia faba during stomatal opening. Planta 110: 63-70.

Arntzen, C. J., M. Haugh, and S. Bobick. 1973. Induction of stomatal closure by Helminthosporium maydis pathotoxin. Plant Physiol. 52: 569-574.

Brown, W. V., H. Mollenhauer, and C. Johnson. 1962. An electron microscope study of silver nitrate reduction in leaf cells. Amer. J. Bot. 60: 5763.

Crout, J. R., and R. B. Jennings. 1957. An improved histochemical method for the demonstration of potassium. J. Histochem. Cytochem. 5: 170-177.

Dayanandan, P., AND P. B. Kaufman. 1973. Stomata in Equisetum. Can. J. Bot. 51: 1555-1564.

Evans, L. T., and W. G. Allaway. 1972. Action spectrum for the opening of Albizzia julibrissin pinnules, and the role of phytochrome in the closing movements of pinnules and of stomata of Vicia faba. Aust. J. Biol. Sci. 25: 885-93.

Fischer, R. A. 1968. Stomatal opening: role of potassium uptake by guard cells. Science 160: 784785

-1972. Aspects of potassium accumulation by stomata of Vicia faba. Aust. J. Biol. Sci. 25: 11071123.

Fujino, M. 1967. Role of adenosinetriphosphate and adenosinetriphosphatase in stomatal movement. Sci. Bull. Fac. Educ. Nagasaki Univ. 18: 1-47.

- 1969. Effect of monoiodoacetic acid on stomatal movement. Sci. Bull. Fac. Educ. Nagasaki Univ. 20: 57-66.

Humble, G. D., and T. C. Hsiao. 1970. Lightdependent influx and efflux of potassium of guard cells during stomatal opening and closing. Plant Physiol. 46: 483-487.

—_, AND K. RASCHKE. 1971. Stomatal opening quantitatively related to potassium transport. Evidence from electron probe analysis. Plant Physiol. 48: 447-453.

ILJIN, W. S. 1957. Drought resistance in plants and physiological processes. Annu. Rev. Plant Physiol. 8: 251-274

IMAMURA, S. 1943. Untersuchungen über den Mechanismus der Turgorschwankung der Spaltöffnungsschliess zellen. Jap. J. Bot. 12: 251-346.

LAUCHLI, A. 1972. Electron probe analysis, p. 191236. In Microautoradiography and electron probe analysis, U. Luttge [Ed.]. Springer-Verlag.

Lloyd, F. E. 1925. The cobalt sodium hexanitrite reaction for potassium in plant cells. Flora 119: $367-385$.
Macallum, A. B. 1905. On the distribution of potassium in animal and vegetable cells. J. Physiol. (Lond.) 32: 95-128.

MANSFIELd, T. A. ANd R. J. Jones. 1971. Effects of abscisic acid on potassium uptake and starch content of stomatal guard cells. Planta 101: 147-158.

Metzner, H. 1952. Die Reduktion wässriger Silbernitratlosungen durch Chloroplasten und andere Zellbestandteile. Protoplasma 41: 129-167.

PaLlaghy, C. K. 1971. Stomatal movement and potassium transport in epidermal strips of Zea mays: the effect of $\mathrm{CO}_{2}$. Planta 101: 287-295.

Pallas, J. E. 1972. Photophosphorylation can provide sufficient adenosine $5^{\prime}$-triphosphate to drive $\mathrm{K}^{+}$ movement during stomatal opening. Plant Physiol. 49: 649-650.

- AND B. G. WRIGHT. 1973. Organic acid changes in the epidermis of Vicia faba and their implication in stomatal movements. Plant Physiol. 51: 588-590.

Rabinowitch, E. I. 1945. Photosynthesis. Vol. 1. Interscience Publishers. 270-271.

Raschke, K., and M. P. Fellows. 1971. Stomatal movement in Zea mays: shuttle of potassium and chloride between guard and subsidiary cells. Planta 101: 296-316.

— anions required by opening stomata of Vicia faba: guard cells release hydrogen ions. Planta. 115: $47-57$.

Sawhney, B. L., AND I. Zelitch. 1969. Direct determination of potassium ion accumulation in guard cells in relation to stomatal opening in light. Plant Physiol. 44: 1350-1354.

SNow, A. G. 1936. Transpiration as modified by potassium. Plant Physiol. 11: 583-594.

Thomas, D. A. 1970 . The regulation of stomatal aperture in tobacco leaf epidermal strips. I. The effect of ions. Aust. J. Biol. Sci. 23: 961-979.

1971. The regulation of stomatal aperture in tobacco leaf epidermal strips. III. The effect of ATP. Aust. J. Biol. Sci. 24: 689-707.

TURNER, N. C. 1973. Action of fusicoccin on the potassium balance of guard cells of Phaseolus vulgaris. Amer. J. Bot. 60: 717-725.

WeEvers, T. H. 1911. Untersuchungen über die Lokalisation und Funcktion des Kaliums in der Pflanze. Recl. Trav. Bot. Neerl. 8: 289-332.

Willmer, C. M., AND T. A. Mansfield. 1970. Further studies on cation-stimulated stomatal opening in isolated epidermis. New Phytol. 69: 639-645. - AND J. E. Pallas. 1973. A survey of stomatal movements and associated potassium fluxes in the plant kingdom. Can. J. Bot. 51: 37-42. , ET AL. 1973. Detection of high levels of phosphoenolpyruvate carboxylase in leaf epidermal tissue and its significance in stomatal movements. Life Sci. Vol. 12, Part II: 151-155.

YaMASHITA, T. 1952. Influences of potassium supply upon various properties and movement of the guard cell. Sieboldia 1: 51-70. 